\title{
Tort Bonding Sale Agreement (SPA) Made by Notary (Study Decision Number: 17 / Pdt.G / 2011 / PN.Smg)
}

\author{
Fertin $^{1}$ and Lathifah Hanim ${ }^{2}$
}

\begin{abstract}
SPA is a preliminary agreement on the purchase agreement of land rights which the agreement will be drawn up and signed in the presence of PPAT, a description of relevant scientific writing case of default in Decision 17 / Pdt.G / 2011 / PN.Smg. Issues examined in this study is enforceable agreement of sale and purchase agreement (SPA) Notary as evidence of authentic, legal consequences if one of the parties in the agreement binding sale and purchase (SPA) has been in default as well as legal protection of the fulfillment of the rights of parties where one party is in default in a binding sale and purchase agreement. The method used in this research is the socio-legal approach that comes from the collection of the data obtained from the primary data and secondary data, and then analyzed by qualitative analysis method. The study provides an answer that the legal force PPJB made before a notary public as authentic evidence in the transfer of rights agreement is very strong. Regarding the legal consequences if one party has been in default then the agreement was null and void, in addition to the legal protection of the fulfillment of the rights of the parties where one party is in default is a return to power of the SPA were made, namely if made before a Notary Public, perlindunganya force in accordance with the protection of an authentic agreement.

Keyword: Bonding Sale Agreement (SPA); Notary; Legal Consequences.
\end{abstract}

\section{Introduction}

Sale and purchase is an agreement, meaning that he was born as a legal agreement (binding or legally enforceable) on the second achievement of agreement between the seller and the buyer on the elements essential (esenselia) ie goods and prices, even selling it on goods that do not move. ${ }^{3}$

Prior to buying and selling along with the actual transfer of rights before the competent authorities of the parties undertake binding sale and purchase agreement to safeguard the rights and obligations of the parties. The binding purchase agreement is a preliminary agreement on the purchase agreement of land rights aktanya will be made and signed in front of the Land Agreement Official (PPAT). On binding sale and purchase agreement (SPA) that the parties will make buying and selling has been bound and a right and an obligation to meet the performance and cons achievement as agreed in a binding sale and purchase.

Binding agreement selling itself is not regulated in the legislation relating to land rights agreements binding sale and purchase of a progresive law in the transition of land rights, so that the position and how the power of the law of treaties binding sale and purchase of sometimes questionable on the implementation of the sale and purchase rights above the ground. ${ }^{4}$ In its implementation, the agreement does not always run in accordance with the desired agreement by the parties. In certain circumstances may arise a problem that resulted in broken promises / default. Some of these forms of broken promises that occurred in the implementation of the agreement binding sale and purchase of the delay in

\footnotetext{
${ }^{1}$ Master of Notary's Student Sultan Agung Islamic University (UNISSULA) Semarang email frtn.cltk@yahoo.com

2 Lecturer of Faculty of Law UNISSULA

${ }^{3}$ Ahmadi Miru and Sakka Pati 2011 Hukum Perikatan: Penjelasan Makna Pasal 1233 sampai 1456 $B W$ Jakarta: Rajawali Press p.80

${ }^{4}$ Author interview excerpts with Achmad Budi Santoso SH M.Kn as a Relation Head Section of the National Land Agency (BPN) Pekalongan The National Land Agency in Pekalongan on June 272018.
} 
payment from the buyer, the seller who sells the object of buying and selling to another party, the seller who is not doing his duty as not submit proof of land ownership is also a certificate to the buyer, do not hand over to the buyer purchase the object, and the object makes buying and selling as collateral in the bank, sell or rent to others.

In line with the above, the description of the case in scientific writing is on the Decision No.17 / Pdt.G / 2011 / PN.Smg between Ispriyanto and Wahyuning Sri Suherti as the plaintiff by Setyo Santoso and Ika Mukarso Rosdiana as defendants where that the principal case filed by the plaintiff explained that defendant for various reasons that are unfounded, the Defendants have been in default that harm the plaintiffs as a buyer acting in good faith, in this case the defendant has done unapropriation in the purchase agreement with the defendant's rights to land.

\section{Research Methods}

This research is empirical juridical approach. Juridical empirical approach was used to analyze the strength of the legal agreement of sale and purchase agreement (SPA) Notary as evidence authentic in the agreement transfer of rights, the legal consequences if one of the parties in the agreement binding sale and purchase (SPA) has been in default as well as legal protection of the fulfillment of rights the parties where one party is in default in a binding sale and purchase agreement. While the approach of normative legal research is research that refers to the norms and principles of law contained in the legislation and court rulings.

\section{Results And Discussion}

\subsection{Severability Of Sale and Purchase Agreement Made In front of a Notary}

Research into legal force on the binding agreement of sale and purchase agreement (SPA) can now be said to be susceptible to a problematic that can be detrimental to one of the parties had agreed, as in the case of Decision 17 / Pdt.G / 2011 / PN.Smg which has do unapropriation.

The binding sale and purchase is an agreement between the seller and the buyer prior to the implementation of purchase due to the causa that must be met for the sale and purchase of these include land title certificates have not been registered in the name of the seller and is still in the process of change the name, and yet the redemption price the object of purchase or the certificate. ${ }^{5}$

In the Regulations on land rights, including the Regulation of the Minister of Agriculture No. 3 of 1997 on the Implementation of Government Regulation No. 24 of 1997 and others, stipulated that any legal actions relating to land rights, every person who will take legal actions relating to land rights shall be subject to all regulations related to land rights. Prior to the transfer of land rights before the competent authority the parties must comply with the requirements in advance, but if the requirements are not met then the signing of the agreement of sale of land rights can not be done in the presence of competent authorities, In order to safeguard the interests of the parties then made Agreement Sale and Purchase agreement (SPA), where it already binds and regulates the transfer of land rights. Agreement Binding of buying and selling is done before a Notary.

Based on the information presented above it can be concluded that the strength of the binding law of the agreement of sale and purchase agreement of land rights Notary Agreement of Sale in the manufacturing operations of purchasing is very strong. This is due to the Sale and Purchase Agreement (SPA) made before a notary an authentic act in accordance with Article 1868 of the Civil Code which states "suata authentic is a agreement made in the prescribed form legislation by or before the employees of the

${ }^{5}$ R. Subekti 1987 Hukum Perjanjian Bandung: Bina Cipta p.75 
general ruling, at the place where the agreement was made.

\subsection{Effects If One Party In the Sale Agreement}

Land purchase agreement by Boedi Harsono is a legal action in the form of delivery of property (land surrender forever) by the seller to the buyer, who at the time also gave the price to the seller. As for the legal acts in the land purchase of customary law are cash, bright and real.

In the purchase agreement, there are two main obligation of the seller to the buyer so that when the price of such goods have been paid for by the buyer, namely: ${ }^{6}$

- Deliver goods sold to the buyer;

- Underwrite or guarantee the goods.

In binding sale and purchase agreement contained the rights and obligations of the parties as such term is binding and requires the parties to fulfill the mutual rights and obligations. But in some cases there are parties that do not meet the achievements of the binding sale and purchase agreement is with the rights and obligations of each of the parties. According to the provisions of Article 1234 Book of the Civil Law, there are three possible forms of achievement, ie giving something, do something, or not do something. Achievement to give something aimed at handing an object to be enjoyed or owned or restore an object to be controlled or enjoyed by the creditor, such as a lease agreement or purchase agreement.

So when one of the parties to the agreement do not carry out the achievements that have been agreed upon, then the other party in the agreement are entitled to enforce its implementation through the mechanisms and pathways applicable law. Coercion entry into force and implementation of the agreement can only be carried out by one or more parties to the agreement of the other party in the agreement as affirmed in principle the personnel of an agreement.

\subsection{Legal Protection Against Fulfilling the Rights of the Parties When One Party Make Default In the Sale and Purchase Agreement}

The protection can be provided if one of the parties in default in a binding sale and purchase agreement: ${ }^{7}$

\subsubsection{Protection against the prospective seller}

Legal protection can be given to the prospective seller usually is in the form of requirements that are usually requested by the prospective sellers themselves. For example, there are a few potential sellers in the agreement binding sale and purchase made request to the buyer in order to make a payment of money the buyer to a specific period which is accompanied by terms void, for example, if the buyer does not meet the payment, as has been requested and agreed the treaty binding sale and purchase rights on land that has been made and agreed to be canceled and the seller usually will not returns the money has been paid unless the buyer requests an exception.

\subsubsection{Protection against the prospective buyer}

In contrast to the protection of the protection seller to the buyer usually executed with requirements are also followed by an authorization request can not be withdrawn. The objective is when the seller does not fulfill the buyer can sue and and ask for compensation in accordance with the agreements stipulated in the binding sale and purchase agreement.

\footnotetext{
${ }^{6}$ Lumban Tobing 1980 Peraturan Jabatan Notaris Jakarta: Publishing p. 31

${ }^{7}$ Author interview excerpts with Handojono Halimana as a Notary Public \& PPAT Pekalongan Notary Office \& PPAT Handojono Halimana SH in Pekalongan on January 142018.
} 
Terms are usually requested by the purchaser for its protection is to request that the certificate or the mark of property rights over the land held by the third party is usually a Notary Public or other parties appointed and agreed upon by the seller and the buyer. Besides other protection is with an authorization agreement can not be withdrawn if all the requirements have been met to make a purchase, then the party may transfer rights pemebeli although the seller did not attend the signing of the agreement of sale purchasing.

Based on all the information above shows that legal protection can be given to the fulfillment of the rights of all parties in a binding sale and purchase in addition to appropriate legal protection provided by the power of the authentic act can also be based on Article 1338 of Law Book of the Civil Code, as well as the goodwill of the parties to fulfill the agreement that has been made.

\section{Closing}

\subsection{Conclusion}

- Legally enforceable agreement of sale and purchase agreement (SPA) Notary as evidence authentic in the agreement transfer of rights is very strong, because the agreement is a agreement notaril that is both authentic act, other than that an authorization can not be withdrawn in the agreement binding sale and purchase is not belong to the absolute power that is prohibited by the Minister of the Interior Instruction No. 14 of 1982 on the Prohibition of Use power of absolute for Assignment of Land, so that its legal status is legitimate to do.

- The legal consequences if one of the parties in the agreement binding sale and purchase (SPA) has been in default is the agreement was null and void, but one of the parties has been bad faith by not want to carry out what are the rights and obligations to a treaty binding sale and purchase rights the soil must carry the compensation to the injured party, but if the question of the civil suit to the local court, the parties should be subject to judicial decisions has permanent legal force.

- Legal protection of the fulfillment of the rights of the parties where one party is in default under the agreement binding sale and purchase is returned to the power of binding agreement purchase is made, that if made by agreement under the hands of the protection in accordance with the protection of the agreement under the hand, whereas if made by or in the presence of a Notary Public, by itself aktanya be agreement notaril so perlindunganya force in accordance with the protection of an authentic agreement.

\subsection{Suggestion}

- Preferably the binding sale and purchase further stipulated in the legislation, especially with regard to land issues, so that the parties put on the binding sale and purchase as a preliminary agreement to buy and sell land rights be protected.

- Notary in the Agreement of Sale and manufacture of purchasing must explicitly write in the chapters about the clause of default so that the parties to both sellers and buyers obtain legal protection.

\section{References}

[1] Ahmadi Miru and Sakka Pati 2011 Hukum Perikatan: Penjelasan Makna Pasal 1233 sampai 1456 BW Jakarta: Rajawali Press

[2] R. Subekti 1987 Hukum Perjanjian Bandung: Bina Cipta

[3] Lumban Tobing 1980 Peraturan Jabatan Notaris Jakarta: Publishing

[4] The Book of the Civil Law (Civil Code)

[5] Regulation of the Minister of Agriculture No. 3 of 1997 on the Implementation of Government Regulation No. 24 of 1997 